огромной ролью англоязычных стран на мировой геополитической арене и английского языка как языка международного.

Заметной причиной заимствования английских слов является также активная американская культурная экспансия.

\title{
Литература:
}

1. Пристайко Т.С., Зеленцова М.Г. «Чужие» среди «своих»: заимствования-метафоры в экономической терминосфере русского языка. Русистика. Київ, 2006. Вып. 5-6. С.11-15.

2. Еловченкова И.А. Лексико-семантическая адаптация английских заимствований экономической тематики (на материале языка прессы начала 21 века): [английские заимствования в русском языке]. Англістика та американістика. Дніпропетровськ : ДНУ, 2005. Вип. 2. С. 21-26.

3. Ивина Л.В. Лингво-когнитивные основы анализа отраслевых терминосистем (на примере англоязычной терминологии венчурного финансирования): Учебно-методическое пособие. М.: Академический Проект, 2003. 304 с.

4. Коновалова Е.А. Заимствование как один из способов пополнения экономической терминологии. Филологические студии. 2001. № 3. С. 95-103.

DOI https://doi.org/10.30525/978-9934-26-110-7-6

\section{УКРАЇНСЬКИЙ КОНФЕСІЙНИЙ ТЕКСТ У ВИМІРАХ СУЧАСНОЇ ЛІНГВІСТИКИ (НА МАТЕРІАЛІ ПРОПОВІДЕЙ ВАСИЛЯ ЛИПКІВСЬКОГО)}

\author{
Павлова I. Г. \\ кандидат філологічних наук, доцент, \\ завідувач кафедри украӥнської мови \\ Полтавський національний педагогічний \\ університет імені В. Г. Короленка \\ м. Полтава, Украӥна
}

Національна лінгвістика нині активно розвивається в руслі нових підходів до розуміння ролі людини й мови в сучасних різновекторних процесах, зорієнтованих водночас і на світові наукові, полікультурні вимоги, і на потреби українського соціуму в усіх царинах. Текстові як 
результату взаємодії індивіда 3 довкіллям, маркерові його комунікативних компетентностей i засобу входження в розхристане сьогодення належить виняткова роль. Надміру політизований і не завжди національно орієнтований український інформаційний обшир загалом та, зосібна, мережевий, теле- й радіоскладник його з численними пастками для непідготовлених споживачів щодня змушує ставити складні питання: «Що читати? Текстам чийого авторства віддавати перевагу? Кого 3 блогерів послухати? Кому 3 відомих журналістів довіряти? Чиїм дослідженням варто приділити увагу? У якій Церкві шукати життьові орієнтири? Хто нині найбільше впливає на розвій суспільства? Який навчальний курс опанувати, щоб сформувати нові компетентності?» У відповідях на них - небайдужість, активна позиція і пошук особистостей із високим рівнем мовної свідомості, які продукують не патогенні тексти. Отже, Людина й породжений нею Текст, пропущений через особистісні, соціальні, нейрофізіологічні «очисники», сформовані середовищем i актуалізовані ситуацією, окреслюють рівень фаховості в системі освіти, досконалості державних інституцій, впливовості Церкви, розвиненості культури, міцності економіки.

Результативна взаємодія з конфесійними усними чи друкованими текстами того чи того жанру має бути надзвичайно відповідальною. Принагідно зауважимо, що «релігійність - це істотний екзистенційний складник характеру суб'єкта (особистості чи групи), яка надає ... ціннісним орієнтаціям, світогляду, переконанням, вірі ... релігійного змісту та скерування. Тому особливості релігійності нації-істотний прояв і чинник іiї спрямованості, а відтак, іiі культури, цивілізованості, історії, що, своєю чергою, визначає спосіб та якість життя й почування громадян створеної нею держави... Гуманістична спрямованість релігійності нації свідчить, зокрема, про іiі перспективність щодо духовного та соціально-економічного прогресу попри всі іï трагічні й драматичні колізії... Ця позиція відповідає загальновизнаному концепту, доведеному видатним французьким соціальним психологом і соціологом Гюставом Лебоном (1841-1931), згідно з яким, релігійні вірування завжди були і $є$ найважливішим елементом ... в історії... В усі періоди існування людства основними питаннями були релігійні.» [3, с. 151-152]. 3-поміж жанрів конфесійного мовлення проповідь (православна, грекокатолицька чи протестантська) $є$ найбільш функційно виразною для формування й употужнення релігійності людини в Україні. Під час породження релігійного мовлення в тій чи тій формі священнослужитель Православної Церкви України, Української Греко-Католицької Церкви чи Церкви Свангельських Християн-Баптистів має пам'ятати про 
обгрунтовані психологами чинники релігійності українців (геополітичне становище нашої держави між Сходом і Заходом, селянська психологія, вдача, що корелюють із такими рисами релігійності українців, як «пантеїзм, обрядовір'я, гумористично-вільнодумний скепсис щодо суворо-імперативного сакрального», «домінувальна зорієнтованість української художньої літератури, усього мистецтва на християнські духовно-моральні цінності», «інтровертизм, емотивність, кардоцентризм, індивідуалізм» [там само, с. 152-157], оскільки вони окреслюють спектр надзвичайно чутливих ментально проблем української християнської історії, національної культури, літератури, Слова в Церкві тощо.

Конфесійний текст, як загалом i тексти інших функційностилістичних різновидів нашої мови, - об'єкт вельми унікальний у часопросторі сучасного мовознавства, особливо тих його напрямків, котрі виформувалися на покордонні лінгвістики й інших наук як згадувана вище нагальна вимога сьогодення в руслі антропоцентризму (лінгвопрагматика, соціолінгвістика, лінгвокультурологія, лінгвогендерологія, еколінгвістика, лінгвоперсонологія, психолінгвістика, лінгвокогнітологія тощо). Для ілюстрування висловлених міркувань ми обрали фрагменти проповідей Василя Липківського, оскільки саме вони відповідають настановам творення національно орієнтованих текстів, у яких мовні засоби оприявнюють та вияскравлюють позамовне національне, культурне, релігійне й історичне тло, уможливлюють правильне (об'єктивне) розуміння індивідом проповідуваних істин, адекватне емоційне сприймання їх та вибудовування поведінкових механізмів: ... А скільки мучилась, скільки страждала, сльозами і кров'ю обливалася наша матір Украӥна од иъього зрадництва ї̈ лукавих дітей. На словах, як каже Т. Шевченко, їі любили, за нею падькували, а на ділі з неї сердешної кров, як воду, точили. I не стільки страшні були для України в минулому ї̈ вороги, ї̈ кати-мучителі, скільки ті продажні душі самих же українців, які йшли до ворогів $і$ казали: «Що мені дасте, то я продам вам ї̈». Стармі - за які-небудь чини, ордени, за князівство та дворянство, за ліси та лани, а менші - за срібняки або просто за панську ласку продавали свою матір та ще й помагали ворогам ї̈ нівечити, над нею знушатися... (Проповідь «Зрадник Христа - Юда. Зрадництво рідному народові») [1, с. 149-151); Повірив украӥнський народ... пустив у своє господарство ирього «самарянина» для допомоги. Ой, щзо ж витворяв цей «самарянин» над нашим народом, якою оливою $і$ вином поливав його рани... Найкращих синів його він розвіз по московській землі, забрав від нашого народу його кращих учених, співців, духівників, забрав на свої роботи вільних козаків, став поливати рани нашого 
народу оливою і вином обмосковлення, московської мови, звичаӥв, а на все рідне, украӥнське, наклав заборону... Христос Спаситель нехай буде нам милосердним Самарянином, нехай поливає Він Сам оливу $і$ вино Своєї божественної науки в нашій рідній мові на наші поранені душі, нехай показує найкращчі иляхи до життя. Свята Православна наша Українська Церква ... $є$ той вірний слуга Христа, щзо підійме тепер народ наш від його занепаду... (Проповідь «Український народ у притчі про Самарянина») [1, с. 490-492); ... дякувати милосердному Господу, щуо народ наш відколи вийшов назустріч Женихові-Христу, відколи став християнським, завжди поводив себе, як ті розумні діви, - свічка віри Христової завжди горіла в нашому народові, запаси оливи - любови до Христа й до свого рідного - завжди були великі в ньому... (Проповідь «Розумні діви і світильник православної віри серед українського народу») [1, с. 535-538).; Ясне сонечко нашої церковної волі викликає в нашій Церкві перші рослини рідного життя, відживляє й підносить нашу рідну мову. Як гарно Тарас Шевченко з воскресінням Христа сполучає відродження нашої рідної мови, нашого слова: «Воскресну я, Господь вам скаже, воскресну нині ради них - людей, закованих мойх, убогих, нищих... Возвеличу малих отих рабів німих, а на сторожі коло них поставлю Слово». Любе братерство! ... Про щчо читалась вчорашня Свангелія? Теж про Слово. Споконвіку було Слово, I Слово було у Бога, I Слово було Бог... Словом тут називається Син Божий, Господь наш Ісус Христос. ... В ичі святі дні воскресіння Христового ми вславляємо Його, як Слово життя світу, для нас Слово благодати й істини. ... От через щзо й Т. Шевченко з воскресінням Христа сполучив і воскресіння нашого украӥнського народу... Отже, $і$ ми, украӥнський народ, у иі величні дні воскресіння Божого Слова вшануємо своє слово, свою рідну мову, бо інакше, чи не буде це зневажання того одвічного Божого Слова... (Проповідь «Споконвіку було слово») [1, с. 238-240). Чим цікаві подібні тексти сьогочасній лінгвістиці? 3 огляду на формат пропонованого дослідження узагальнено окреслимо найістотніші складники проблемного поля кожного з напрямків. Переконливі проукраїнська позиція та реформаторська діяльність Отця-Митрополита Української Автокефальної Церкви Василя Липківського виконують виразну текстотвірну функцію, його мовна, мовленнєва, педагогічна, організаторська, дослідницька, релігійно-просвітницька, громадянська, соціокультурна, психологічна компетенції вербалізуються за допомогою вишуканих метафор, епітетів, слів-антонімів, антитез, слів-символів, перифраз, синонімічних одиниць (сонечко церковної волі, рослини рідного життя, поранені душі; величні дні, одвічне Боже Слово; любов - зрадництво, 
старші-менші; «самарянин», рани народу, олива й вино обмосковлення, продажні душі, свічка віри Христової; Син Божий, німі раби, Слово життя світу; Слово, мова, рідна мова; відродження, воскресіння тощо) й оприявнюють елітарну мовну особистість проповідника. Цінність обстежуваних текстів у дотриманні автором мовних норм, у чіткому й послідовному його піклуванні про екологію душі, думки українців, рідного слова, у використанні націєзбережувальних технологій, актуальних і в незалежній Україні. Зміст, мовні засоби проповідей, мовна поведінка й релігійне подвижництво Василя Липківського слугують тлом i водночас маркерами ставлення до Жінки, України, рідної мови, українських пророків, зрадників, рятівників, що втілюється в образахконцептах «Матір Божа», «матір Україна», «розумна діва», «нерозумна діва», «Тарас Шевченко», «лукаві діти», «самарянин» тощо. Перспективним вважаємо дослідження психолінгвістичних і лінгвопрагматичних проблем сприйняття й оцінювання конфесійного тексту, «витягування смислів», прихованих за вербальними засобами, розуміння «комунікативного наміру суб'єктів спілкування», стратегій і тактик, прагматики лексичних і граматичних одиниць, імплікацій та імплікатур спілкування.

\section{Література:}

1. Липківський Василь Проповіді на неділі й свята. Слово Христове до українського народу. США, 1988. 609 с.

2. Методы анализа текста и дискурса. Пер. с нем. / Тичер С. и др. Х. : Гуманитарный Центр, 2017. 356 с.

3. Москалець В. П. Психологія релігії : підручник. К. : Видавництво Лipa-К, 2020. 192 с.

4. Селігей П. О. Мовна свідомість: структура, типологія, виховання. К. : Вид. дім «Києво-Могилянська академія», 2012. 118 с. 